\title{
Life-threatening Consequence of a Psychiatric Behavior
}

\author{
Mirela TIGLIS ${ }^{1,2}$, Andreea Livia DUMITRESCU' ${ }^{1}$, Cristina BOLOGA 1 , Tudor HURMUZACHE? , \\ Alexandru Emil BAETU17, Tiberiu Paul NEAGU3,4, Bogdan SOCEA ${ }^{5,6}$, Ioan LASCAR ${ }^{3,4}$, \\ loana Marina GRINTESCU ${ }^{1,2}$
}

\begin{abstract}
Introduction: The prevalence of hypokalemia in psychiatric population is very high with eating disorders and laxative abuse being the main incriminated factors. Case presentation: We report a case of a 34-year-old woman with history of sleeve gastrectomy and breast implant, who presented for fatigue, severe myalgia, generalized hypotonia and palpitations. Laboratory exams revealed severe hypokalemia and rhabdomyolysis. The electrocardiography showed prolonged QT interval and ST segment depression with second-degree atrioventricular block. She received intravenous potassium supplementation with consecutive hydration. When potassium level was within safety limits, the patients received loop diuretics in order to decrease rhabdomyolysis and avoid kidney injury. The underlying cause was a pathological behavior, with frequent self-provoked episodes of nausea and vomiting after eating and chronic consumption of laxatives. She started psychotherapy. Conclusion: Psychiatric behaviour can lead to life-threatening conditions, therefore it should be discovered and managed promptly.
\end{abstract}

Keywords: hypokalemia, psychiatric behaviour, prolonged QT interval, palpitation, rhabdomyolysis.

\section{Rezumat}

Introducere: Prevalența hipopotasemiei în rândul pacienților psihiatrici este foarte mare, tulburările alimentare și abuzul de laxative fiind principalii factori incriminați. Prezentare de caz: Vă prezentăm cazul unei paciente de 34 ani, cu iantecedente de sleeve gastric și augmentare mamară cu proteze de silicon, care este admisă în unitatea de primiri urgențe pentru oboseală, mialgie severă, hipotonie generalizată și palpitații. Investigațiile de laborator evidențiază hipopotasemie severă și rabdomioliză. Electrocardiografia arată prelungirea segmentului QT, subdenivelare de segmente ST, cu bloc atrioventricular de gradul II. Paxcientei i se administrează clorură de potasiu intravenos, concomitent cu reechilibrarea volemică. În momentul în care nivelul potasiului este în limite de siguranță, se instituie terapie diuretică cu scopul de a reduce rabdomioliza și a evita injuria renală acută. La baza acestor simptome și manifestări clinice și paraclinice se află un comportament patologic, cu episoade de vărsături auto-provocate după ingestia de alimente, precum și consumul cronic de laxative. Pacienta a început sedințele de psihoterapie. Concluzie: Comportamentele psihiatrice pot fi amenințătoare de viață, așadar, ar trebui identificate și tratate cu promptitudine.

Cuvinte cheie: hipopotasemie, comportament psihiatric, interval QT prelungit, palpitații, rabdomioliză.

\footnotetext{
${ }^{1}$ Department of Anesthesiology and Intensive Care, Emergency Clinical Hospital, Bucharest, Romania

${ }^{2}$ Clinical Department No. 14, „Carol Davila” University of Medicine and Pharmacy, Bucharest, Romania

${ }^{3}$ Department of Plastic Surgery and Reconstructive Microsurgery, Emergency Clinical Hospital, Bucharest, Romania

${ }^{4}$ Clinical Department No. 11, "Carol Davila" University of Medicine and Pharmacy, Bucharest, Romania

${ }^{5}$ Department of General Surgery, „Sf. Pantelimon" Emergency

Clinical Hospital, Bucharest, Romania

${ }^{6}$ Clinical Department No. 10, "Carol Davila" University of Medicine and Pharmacy, Bucharest, Romania
}

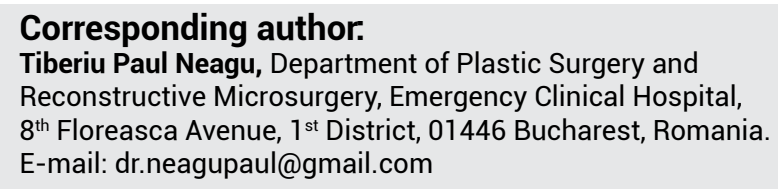




\section{INTRODUCTION}

A wide spectrum of clinical manifestations can be produced by hypokalemia, from fatigue, muscle weakness and paralysis, to disorientation, irritability, confusion, headache and finally to rhabdomyolysis or life-threatening arrhythmias ${ }^{1}$. In the presence of very low serum potassium levels, the risk of sudden death is very high ${ }^{2}$. Studies have shown that the prevalence of hypokalemia in psychiatric population can rich $20 \%$, higher than the general population ${ }^{3}$. Eating disorders represent the $12^{\text {th }}$ cause of impaired functionality in women worldwide ${ }^{4}$. In patients with eating disorders, the incidence of hypokalemia is $0-23 \%$ while of hypochloremia is $9-26 \%$. Another frequent problem in this subgroup of patients is the laxative abuse, with consecutive electrolyte imbalance and dehydration ${ }^{5}$. The incidence of laxative abuse in patients with eating disorders is about $8-36 \%{ }^{6}$. In view of these, we present a case of a patient with severe hypokalemia apparently without causes, which in fact was the consequence of a psychiatric behavior.

\section{CASE PRESENTATION}

A 34-year-old female with history of sleeve gastrectomy and breast implants, presented to our hospital for fatigue, severe myalgia, generalized hypotonia and palpitations. In the emergency department, an electrocardiography was performed showing a sinus rhythm, prolonged QT interval, ST-segment depression in V3-V6 derivations and second-degree atrioventricular block (Figure 1). Laboratory exams revealed severe hypokalemia $(1.1 \mathrm{mEq} / \mathrm{L})$, severe rhabdomyolysis, hypochloremia and mild hyponatremia. In Table 1 there are presented several laboratory studies from the first 12 hours. A central venous line was inserted for potassium supplementation and the patient was transferred into ICU (Intensive Care Unit) for further management. At clinical examination, she appeared alert, cooperative but sleepiness and irritated. The skin was normal, with warm extremities and without teeth decalcifications. She could breathe normally. The pulse presented some abnormalities and the blood pressure was low. The ab-

Figure 1. Electrocardiography.

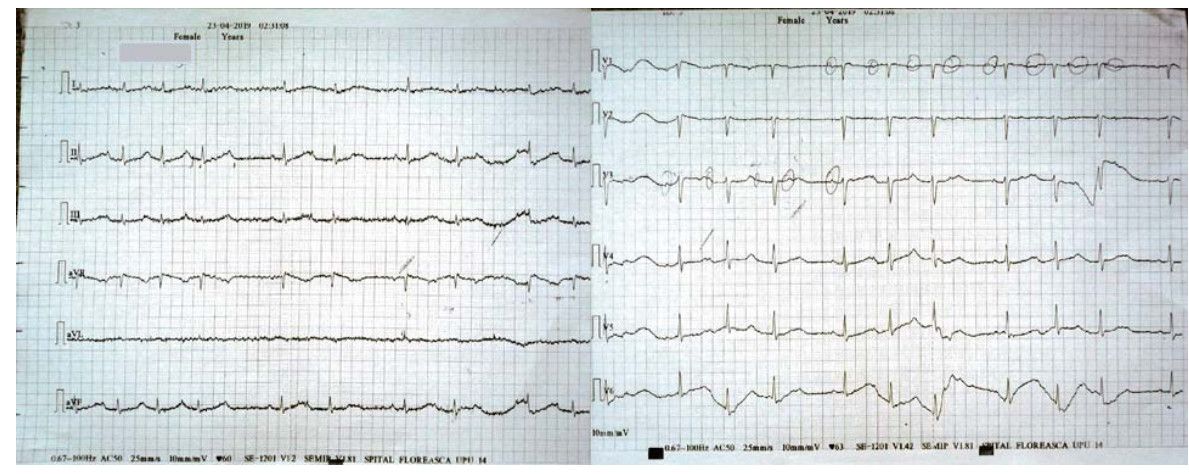

Trend of serum potassium changes

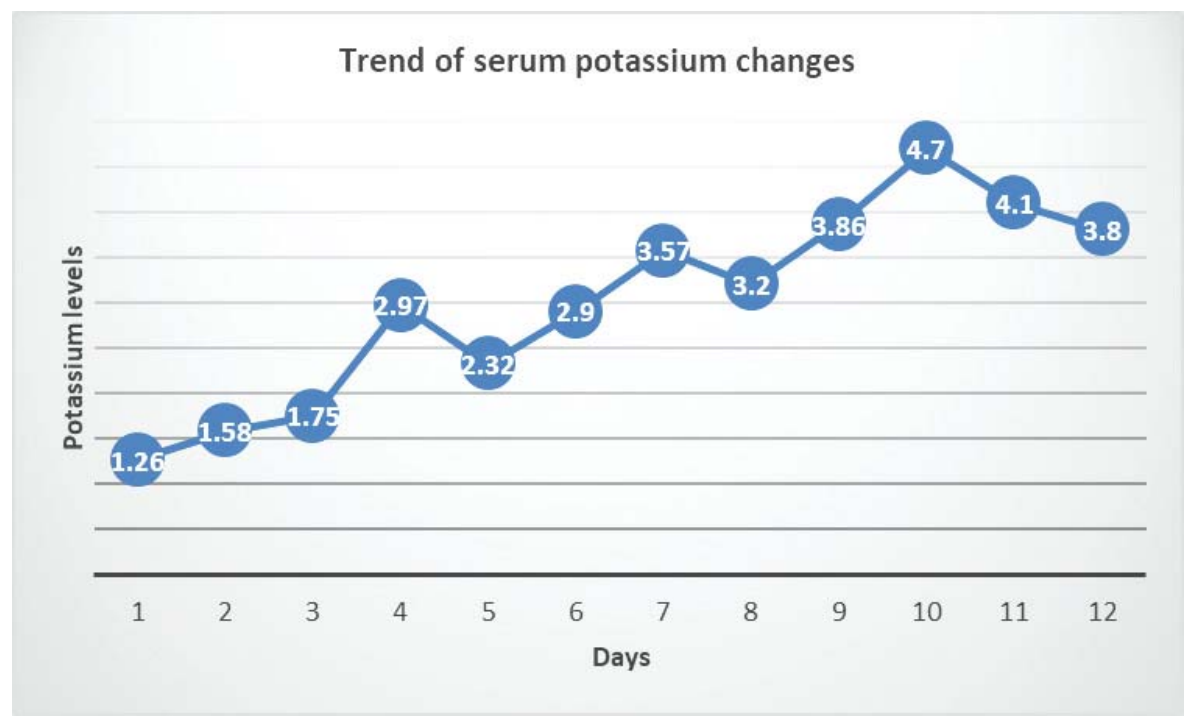

Figure 2. Trend of serum potassium changes. 
Figure 3. Trend of serum creatine kinase correction.

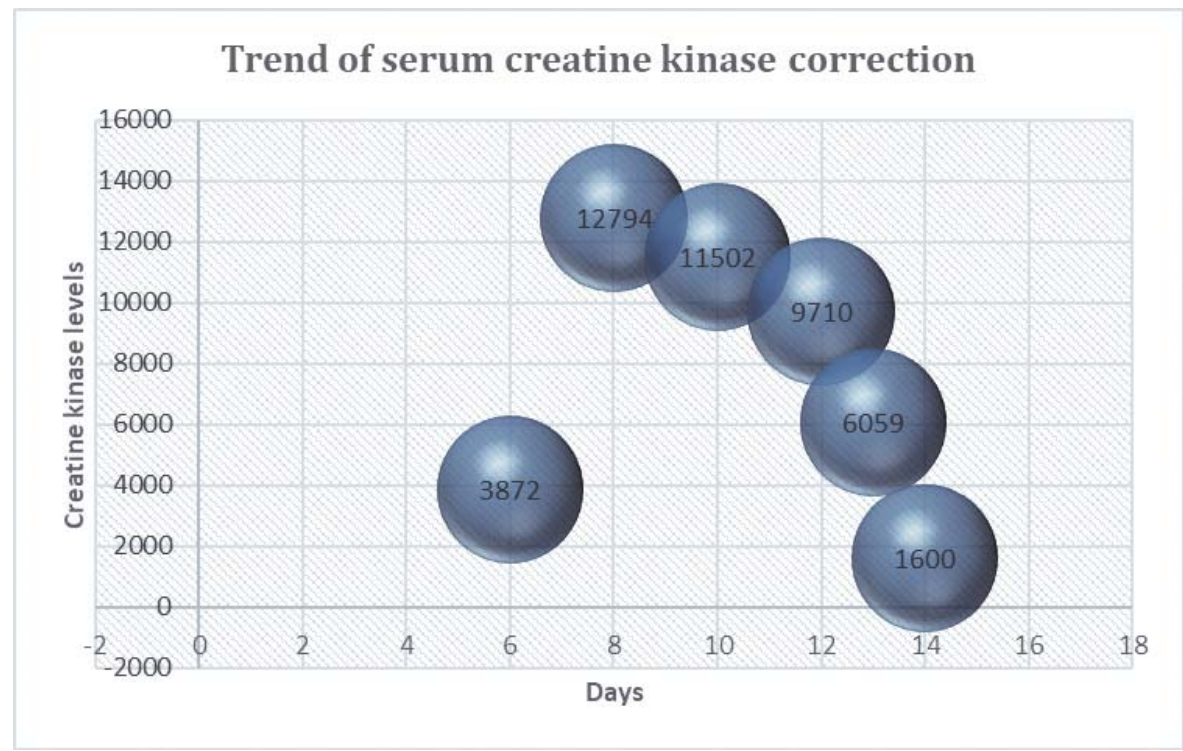

Table 1. Arterial blood gase analysis (ABG) from the first 12 hours

\begin{tabular}{|l|c|c|c|c|}
\hline & ABG 1 & ABG 2 & ABG 3 & ABG 4 \\
\hline $\mathrm{pH}$ & 7.44 & 7.49 & 7.43 & 7.39 \\
\hline $\mathrm{K}^{+}(\mathrm{mEq} / \mathrm{L})$ & 1.1 & 1.1 & 1.4 & 1.1 \\
\hline $\mathrm{Na}^{+}(\mathrm{mEq} / \mathrm{L})$ & 132 & 133 & 138 & 136 \\
\hline $\mathrm{Cl}^{-}(\mathrm{mEq} / \mathrm{L})$ & 93 & 95 & 104 & 101 \\
\hline $\mathrm{Ca}^{2+}(\mathrm{mmol} / \mathrm{L})$ & 1.22 & 1.27 & 1.39 & 1.35 \\
\hline Bilirubin $(\mathrm{mg} / \mathrm{dL})$ & 4 & 4.4 & 3.8 & 3.6 \\
\hline Lactate $(\mathrm{mmol} / \mathrm{L})$ & 1.2 & 0.9 & 0.6 & 0.8 \\
\hline
\end{tabular}

domen was flat, soft and she had healthy weight. Muscular strength was 1 on a scale of 5 and she described frequent muscular cramps, pain and extreme thirst. She also presented polyuria. In the ICU, the hypokalemia correction with intravenous continuous infusion of potassium chloride continued. When serum potassium levels began to rise, fluidic and loop diuretic infusions were started in order to decrease creatine kinase levels secondary to rhabdomyolysis and prevent renal injury. She also received ulcer and thromboembolic prophylaxis. An abdominopelvic computed tomography examination was performed but there were no pathological findings that could explain the severe onset of hypokalaemia. The trend of correcting potassium values was slow (Figure 2) with a transtubular potassium gradient (TTKG) of 10.5 in the third day of ICU stay. After various discussions, the patient confirmed the fact that she used to have pathological behaviors, with frequent self-provoked episodes of nausea and vomiting after eating and chronic consumption of laxatives. She accepted to begin psychotherapy. After 4 days the potassium level was normal, the electrocardiography did not present any changes, the rhabdomyolysis syndrome had a descendent trend (Figure 3), the myalgia and muscular cramps improved and the patient could move by herself. Therefore, she was discharged into the medical ward for further management.

\section{DISCUSSION}

Hypokalemia can have various underlying conditions, especially gastrointestinal or renal losses, inadequate intake, medications (diuretics, laxatives, amphotericin $\mathrm{B}$ and cisplatin), excessive exercise and the use of "sauna suits", extensive burns with cutaneous losses, primary or secondary hyperaldosteronism or psychiatric disorders ${ }^{7,8}$.

In the presence of severe hypokalemia, as in the case of our patient, the risk of sudden death is high, due 
to prolonged QTc intervals that can lead to torsade de pointes ${ }^{9}$. The intravenous potassium supplementation should be started without hesitation. A study published by Vo M. and colab. showed that patients with eating disorders tend to have bradycardia and orthostatic hypotension ${ }^{10}$, in contrast to our case, where tachycardia was present.

Roering and colab. published a study about medical complications of eating disorders in about $1000 \mathrm{pa}^{-}$ tients. They found out that young female were more affected (more than $90 \%$ of patients), with an average age of 28 years. The primary complications were low albumin levels, vitamin D deficiency, leukopenia, osteoporosis, metabolic alkalosis, hypokalemia, longer QTc intervals, hyponatremia, hypophosphatemia and hypoglycaemia ${ }^{4}$.

Studies have shown that "binge-purge behavior", the consumption of a large quantity of aliments followed by self-induced vomiting and abuse of diuretics or laxative, range from $25 \%$ in adults to $90 \%$ among young girls 5 . These patients can develop acute gastric dilatation, which can be life threatening besides electrolyte imbalances ${ }^{11}$. Hyponatremia is frequently found, but in this case, it had only a small decrease.

Despite her pathological behavior, our patient had healthy weight. She also had no teeth decalcifications, dental erosion or caries and periodontal diseases, which are frequently found in patients with this type of disorders, due to gastric acidity ${ }^{12}$.

As we have emphasized before, in the presence of eating disorders, the laxative consumption is common ${ }^{6}$.

\section{References}

1. Hong E. Hypokalemia and Psychosis: A forgotten association. American Journal of Psychiatry Residents' Journal. 2016 Nov 1;11(11):6-7.

2. Roerig JL, Steffen KJ, Mitchell JE, Zunker C. Laxative abuse. Drugs. 2010 Aug 1;70(12):1487-503.

3. Lam MH, Chau SW, Wing YK. High prevalence of hypokalemia in acute psychiatric inpatients. General hospital psychiatry. 2009 May 1;31(3):262-5.

4. Mehler PS, Blalock DV, Walden K, Kaur S, McBride J, Walsh K, Watts J. Medical findings in 1,026 consecutive adult inpatientresidential eating disordered patients. International Journal of Eating Disorders. 2018 Apr;51(4):305-13.

5. Sato Y, Fukudo S. Gastrointestinal symptoms and disorders in patients with eating disorders. Clinical journal of gastroenterology. 2015 Oct 1;8(5):255-63.

6. Winstead NS, Willard SG. Gastrointestinal complaints in patients with eating disorders. Journal of clinical gastroenterology. 2006 Sep 1;40(8):678-82.

7. Groeneveld JH, Sijpkens YW, Lin SH, Davids MR, Halperin ML. An approach to the patient with severe hypokalaemia: the potassium quiz. Qjm. 2005 Mar 10;98(4):305-16.
Our patient used them to remove the ingested calories and remain thin. In reality, only a small percentage of about $10 \%$ of ingested calories can be lost in this manner, as the laxative does not have a significant effect on small bowel, the primary site for calories absorption ${ }^{13}$. Nevertheless, laxative abuse leads to electrolyte imbalance and dehydration, often accompanied by postural dizziness, muscle weakness and syncope ${ }^{2}$.

\section{CONCLUSION}

Psychiatric behaviour can lead to life-threatening conditions, severe hypokalemia rising specific problems in terms of arrhythmic complications. Therefore, potassium correction by administration of potassium chloride should be started immediately. The association between eating disorders, with self-induced vomiting, and laxative abuse often leads to electrolyte imbalance, dehydration and rhabdomyolysis. In patients with eating disorder, the therapeutic intervention should be early performed in order to prevent progression to a critical cardiac, gastrointestinal and psychiatric condition.

\section{Compliance with ethics requirements:}

The authors declare no conflict of interest regarding this article.

The authors declare that all the procedures and experiments of this study respect the ethical standards in the Helsinki Declaration of 1975, as revised in 2008(5), as well as the national law. Informed consent was obtained from all the patients included in the study.

8. Negoescu I, Niculescu DA, David C, Peride I, Niculae A, Checherita IA, Poiana C. Biochemical determinants of aggressive behaviour-patho-physiological connections in esrdand dialysis. Farmacia. 2018 Nov 1;66(6):925-9.

9. Lesinskiene S, Barkus A, Ranceva N, Dembinskas A. A metaanalysis of heart rate and QT interval alteration in anorexia nervosa. The World Journal of Biological Psychiatry. 2008 Jan 1;9(2):86-91.

10. Vo M, Lau J, Rubinstein M. Eating disorders in adolescent and young adult males: presenting characteristics. Journal of Adolescent Health. 2016 Oct 1;59(4):397-400.

11. Patocskai EJ, Thomas JM. Gastric necrosis in a patient with bulimia. The European journal of surgery. 2002 Aug 1;168(5):3024.

12. Romanos GE, Javed F, Romanos EB, Williams RC. Oro-facial manifestations in patients with eating disorders. Appetite. 2012 Oct 1;59(2):499-504

13. Mehler PS. Medical complications of bulimia nervosa and their treatments. International Journal of Eating Disorders. 2011 Mar;44(2):95-104. 